\title{
Moderate and severe pharyngitis in young adult inhabitants of Poznan, western Poland
}

\author{
MACIEJ BURA ${ }^{1, A-G}$, MICHAŁ MICHALAK ${ }^{2, C-E}$, MICHAt CHOJNICK| ${ }^{3, \text { B, E, MAGDALENA PADZIK }}{ }^{4, \mathrm{~B}}$, \\ IWONA MOZER-LISEWSKA ${ }^{1, D, E, G}$ \\ ${ }^{1}$ Department of Infectious Diseases, Hepatology and Acquired Immunodeficiencies, Poznan University \\ of Medical Sciences \\ ${ }^{2}$ Department of Computer Science and Statistics, Poznan University of Medical Sciences \\ ${ }^{3}$ Department of Biology and Environmental Protection, Poznan University of Medical Sciences \\ ${ }^{4}$ Department of Family Medicine, Poznan University of Medical Sciences
}

A - Study Design, B - Data Collection, C - Statistical Analysis, D - Data Interpretation, E - Manuscript Preparation, F - Literature Search, G - Funds Collection

Summary Background. Acute pharyngitis is a frequent clinical problem.

Objectives. To assess: the frequency of streptococcal etiology ( $\beta-\mathrm{HS})$ in moderate to severe pharyngitis among young adult patients, the accuracy of the Centor score (CS) in predicting the likelihood of the $\beta$-HS etiology and the usefulness of the rapid antigen detection test (RADT) in the appropriate selection of patients that ought to be treated with antibiotics.

Material and methods. 202 individuals (101 patients and a sex- and age-matched control group) aged 18-44 participated in the study. Two throat swabs were performed: the first one to carry out RADT for group A streptococci (GAS), and the second one to grow a conventional culture. Data on the antibiotic therapy were recorded as well.

Results. $\beta$-HS were responsible for one-third of the studied cases of pharyngitis (GAS - 22.8\%, 23/101; high non-GAS colony count $-9.9 \%, 10 / 101)$. The frequency of the isolation of $\beta$-HS depending upon the CS was as follows: CS2 - 13.2\% $(5 / 36)$, CS3 - 40.5\% (15/36), CS4-61.5\% (16/36). RADT's effectiveness in identifying GAS was significantly higher than that of CS alone $(p<0.001)$. Antibiotics were prescribed in 59 cases, including $45 \%$ of RADT-negative patients (35/77). The primary choice was penicillin (37.3\%, 22/59).

Conclusions. In young adult pharyngitis patients with $\mathrm{CS} 2-4, \beta-\mathrm{HS}$ are responsible for a minority of cases. Among these bacteria, almost one third are non-GAS. Centor criteria, as the only diagnostic tool in predicting the streptococcal etiology of the disease, are of moderate usefulness. The use of RADT significantly increases the diagnostic accuracy of GAS-related pharyngitis.

Key words: streptococci, pharyngitis, GAS, RADT, non-GAS, Centor score.

Bura M, Michalak M, Chojnicki M, Padzik M, Mozer-Lisewska I. Moderate and severe pharyngitis in young adult inhabitants of Poznan, western Poland. Fam Med Prim Care Rev 2017; 19(1): 12-17, doi: 10.5114/fmpcr.2017.65084.

\section{Background}

Acute pharyngitis can be defined as the co-existence of sore throat, fever, pharyngotonsillar erythema and edema. It constitutes an important problem in the daily practice of general practitioners and is also a frequent cause of consultations in the case of adult patients [1]. In countries with temperate climate (e.g. Poland), the majority of cases occur in winter and early spring, contributing to an increased incidence of respiratory tract infections during this period of the year. Pharyngitis can be caused by a variety of microorganisms, with viruses being the most common. Nevertheless, bacteria are also an important etiologic agent of this clinical syndrome. The role of group $A \beta$-hemolytic streptococci (GAS) in this context is well defined. Due to these facts, pharyngitis is one of the principal causes of the overuse of antibiotics, including broad-spectrum ones as well $[2,3]$.

In spite of the existence of modern national recommendations for the management of pharyngitis [4], real-life practice shows that they are frequently not adhered to. Briefly, a throat culture or a rapid antigen detection test (RADT) should be performed in patients with a Centor score (CS, or Centor criteria) of 2 or 3 , and those in whom group A streptococci (GAS) were detected should be treated with antibiotics. In individuals with 4 Centor criteria, it is recommended to begin empiric therapy, pending the results of microbiological testing. The preferred drug for treating GAS pharyngitis is phenoxymethylpenicillin (penicillin V). The role of $\beta$-hemolytic streptococci belonging to serological groups other than A (non-GAS) in causing pharyngitis and the management of such cases is a controversial issue. To the best of our knowledge, data for adults from Poland are not available.

\section{Objectives}

This study had the following objectives:

- to assess the frequency of streptococcal etiology in moderate or severe pharyngitis (corresponding to at least CS2) in the case of young adult patients aged 18-44, taking under particular consideration non-GAS,

- to assess the adequacy of CS in determining the likelihood of the streptococcal etiology of this clinical syndrome,

- $\quad$ to assess the usefulness of RADT in the appropriate selection of patients that ought to be treated with antibiotics, in accordance with the current national recommendations for the management of acute pharyngitis.

\section{Material and methods}

This prospective case-control study included 101 adult patients aged 18-44 who, in the period from March 1, 2014, to February 28, 2015, went to general practitioners in several 
districts of Poznan (one of the largest cities in Poland, situated in the west of the country), because of sore throat lasting no longer than 7 days (median: 3 days; range: $1-7$ days). Those individuals who had been treated with antibiotics in the period of 4 weeks preceding their recruitment were excluded from this analysis. All patients were assessed for the presence of the so-called Centor criteria, i.e. lack of cough, fever at a level of at least $38^{\circ} \mathrm{C}$, the presence of anterior cervical lymphadenopathy and an exudate on the surface of tonsils. Only patients with at least 2 of these criteria and who agreed to participate in the study were qualified as participants.

Volunteers from the control group, being the inhabitants of the same area, were age- ( \pm 2 years; range: $18-44$ years) and sex-matched to patients. All of them were healthy and had not received any antibiotics in the period of 4 weeks prior to being recruited.

Two throat swabs were taken from each study participant. The first sample was delivered (transport medium: Amies) to a microbiological laboratory (Laboratory of Microbiology of Jozef Strus Multidisciplinary Municipal Hospital in Poznan) within 24 hours from sampling, and the second was immediately used in the office to perform RADT for the qualitative ascertaining of the presence of group A streptococcal antigen (OSOM Strep A Test; Sekisui Diagnostics, LLC, San Diego, California, USA) in accordance with the manufacturer's recommendations. Throat swabbing and the microbiological test for $\beta$-hemolytic streptococci $(\beta-H S)$ were conducted in accordance with the instructions contained in the generally available national guidelines [1]. The growth of the colony of $\beta$-HS was assessed semi-quantitatively in accordance with the following rules: low bacterial growth - within the first quadrant of the plate $(+)$, moderate count - within the second quadrant (++), and abundant growth - within the third or third and fourth quadrant $(+++$ or ++++$)$. Serotyping according to the Lancefield classification (A, B, C, D, F and G) was performed with the use of SLIDEX ${ }^{\circledR}$ Strepto Plus (bioMerieux ${ }^{\circledR}$ SA, Marcy-L'Étoile, France) latex agglutination tests.

All the physicians recruiting patients were trained in correct throat swabbing and performing RADT in accordance with the manufacturer's recommendations. Moreover, they were provided with information regarding the current national recommendations on the treatment of pharyngitis. The final decision on how to proceed and what antibiotic therapy to choose was made in each case by the general practitioner treating the patient and was not influenced by the research team; nevertheless, we recorded all cases when anti-microbial medication was prescribed.

The economic analysis of the costs of diagnosing and treating pharyngitis within this study was conducted upon the basis of the following presumptions:

- the cost of symptomatic treatment is identical for each case, regardless of CS or the result of microbiological diagnostics,

- the cost of a single RADT used in this study amounted to 6 PLN (1.39 EUR),

- the cost of a single culture with serogroup identification in the case of ascertaining the presence of $\beta-\mathrm{HS}$ amounted to 25 PLN (5.80 EUR),

- the cost of the antibiotic therapy matches $100 \%$ of the price of the antibiotic in the Drug Index of Medycyna Praktyczna (Practical Medicine) (available at www. mp.pl, accessed June 25, 2015), whereas the treatment of choice consists in the daily administration of 3 million units of penicillin $\mathrm{V}$ in two divided doses over 10 days,

- the cost of the anti-microbial medications prescribed by the physicians treating the study participants matches $100 \%$ of their prices in the same source, whereas the actual regimen of the antibiotic therapy (dosing and time of treatment) with the use of the cheapest preparation of a given medication was applied, also if it differed from the one suggested in the recommendations.

\section{Statistical analysis}

Numerical data were presented as median and range. Compatibility of data with normal distribution was checked by the Shapiro-Wilks test. Since the data did not follow normal distribution, the comparison between patients and the control group was performed by the Mann-Whitney test. Categorical data were presented as numbers and percentages. The comparison was done by the test for proportions and the chi-square test of independence. Statistical analysis was performed with Statistica 12 (Statsoft, Inc.) software. All tests were considered significant at $p<0.05$.

\section{Ethical approval}

The study was approved by the Bioethics Committee of Poznan University of Medical Sciences (reference number 988/13). A written informed consent was obtained from all study participants.

\section{Results}

The characteristics of all study participants are presented in Table 1. The results of tonsillopharyngeal swab cultures and RADT for the patients and the control group are summarized in Table 2.

\begin{tabular}{|c|c|c|c|}
\hline Variable & $\begin{array}{l}\text { Patients } \\
(n=101)\end{array}$ & $\begin{array}{l}\text { Controls } \\
(n=101) \\
\end{array}$ & $p$-value \\
\hline Median age (range) & $\begin{array}{l}26(18-44) \\
\text { years }\end{array}$ & $\begin{array}{l}26(19-44) \\
\text { years }\end{array}$ & 0.739 \\
\hline Male gender (\%) & $40(39.6 \%)$ & $40(39.6 \%)$ & 1.000 \\
\hline $\begin{array}{l}\text { No. of individuals in } \\
\text { the household (days) }\end{array}$ & $\begin{array}{l}3.1 \pm 1.2 \\
(1-6)\end{array}$ & $\begin{array}{l}3.1 \pm 1.3 \\
(1-6)\end{array}$ & 0.689 \\
\hline $\begin{array}{l}\text { More than } 3 \\
\text { individuals in the } \\
\text { household }\end{array}$ & $32(31.7 \%)$ & $43(42.6 \%)$ & 0.109 \\
\hline $\begin{array}{l}\text { Child/children in the } \\
\text { household }\end{array}$ & $42(41.6 \%)$ & $39(38.6 \%)$ & 0.666 \\
\hline Mean no. of children & $\begin{array}{l}0.6 \pm 0.9 \\
(0-3)\end{array}$ & $\begin{array}{l}0.6 \pm 0.9 \\
(0-3)\end{array}$ & 0.916 \\
\hline $\begin{array}{l}\text { More than } 1 \text { child in } \\
\text { the household }\end{array}$ & $18(17.8 \%)$ & $21(20.7 \%)$ & 0.592 \\
\hline $\begin{array}{l}\text { More than } 2 \text { children } \\
\text { in the household }\end{array}$ & $8(7.9 \%)$ & $3(2.9 \%)$ & 0.121 \\
\hline $\begin{array}{l}\text { Contact with a case } \\
\text { of pharyngitis in the } \\
\text { last week }\end{array}$ & $41(40.6 \%)$ & $32(31.7 \%)$ & 0.187 \\
\hline
\end{tabular}

Table 2. Tonsillopharyngeal swab culture results, RADT results and its performance in study participants $(n=202)$

\begin{tabular}{|l|l|l|l|}
\hline $\begin{array}{l}\text { Result of culture/ } \\
\text { RADT }\end{array}$ & $\begin{array}{l}\text { Controls } \\
(n=101)\end{array}$ & $\begin{array}{l}\text { Patients } \\
(n=101)\end{array}$ & $p$-value \\
\hline Positive culture & $14(13.9 \%)$ & $36(35.6 \%)$ & $<0.001$ \\
\hline GAS & $1(1 \%)$ & $23(22.8 \%)$ & $<0.001$ \\
\hline Non-GAS (any growth) & $13(12.9 \%)$ & $13(12.9 \%)$ & 1.000 \\
\hline $\begin{array}{l}\text { Non-GAS (abundant } \\
\text { growth) }\end{array}$ & $4(3.9 \%)$ & $10(9.9 \%)$ & 0.096 \\
\cline { 2 - 4 } & $\begin{array}{l}\left(n=100^{*}\right) \\
4(4 \%)\end{array}$ & $\begin{array}{l}\left(n=78^{*}\right) \\
10(12.8 \%)\end{array}$ & 0.030 \\
\hline $\begin{array}{l}\text { RADT(+) GAS(+) (true } \\
\text { positive RADT) }\end{array}$ & 0 & 22 & N/A \\
\hline $\begin{array}{l}\text { RADT(+) GAS(-) (false } \\
\text { positive RADT) }\end{array}$ & 4 & 2 & N/A \\
\hline
\end{tabular}




\begin{tabular}{|c|c|c|c|}
\hline $\begin{array}{l}\text { Result of culture/ } \\
\text { RADT }\end{array}$ & $\begin{array}{l}\text { Controls } \\
(n=101) \\
\end{array}$ & $\begin{array}{l}\text { Patients } \\
(n=101) \\
\end{array}$ & $p$-value \\
\hline $\begin{array}{l}\text { RADT(-) GAS(-) (true } \\
\text { negative RADT) }\end{array}$ & 96 & 76 & N/A \\
\hline $\begin{array}{l}\text { RADT(-) GAS(+) (false } \\
\text { negative RADT) }\end{array}$ & 1 & 1 & $\mathrm{~N} / \mathrm{A}$ \\
\hline Sensitivity of RADT & $0 \%$ & $95.7 \%$ & $<0.001$ \\
\hline Specificity of RADT & $96 \%$ & $97.4 \%$ & 0.577 \\
\hline PPV of RADT & $0 \%$ & $91.7 \%$ & $<0.001$ \\
\hline NPV of RADT & $99 \%$ & $98.7 \%$ & 0.841 \\
\hline Accuracy of RADT & $95.0 \%$ & $97.0 \%$ & 0.468 \\
\hline
\end{tabular}

*23 patients and one individual from the control group with S. pyogenes positive culture results were excluded from this analysis.

Abbreviations: GAS, group A $\beta$-hemolytic streptococci (S. pyogenes); non-GAS, other (non-A) groups of $\beta$-hemolytic streptococci; PPV, positive predictive value; NPV, negative predictive value; N/A, not assessed; RADT, rapid antigen detection test.

In the case of all 24 individuals who were culture-positive for GAS (23 patients and 1 individual from the control group), abundant bacterial growth was observed. In the case of patients with identified non-GAS streptococci $(n=13)$, the following representatives were cultured: $C$ group (GCS) -7 cases (with abundant growth in 6 of them), G group (GGS) -4 cases (abundant growth in 3 patients), B group (GBS) - 1 case (abundant growth) and D and F groups (GDS and GFS, respectively) - both in the case of the same patient. In the control group, GCS and GFS were observed respectively in 9 (including an abundant growth in 4 individuals) and 4 cases.

The results of the swab culture from the throat in combination with the number of Centor criteria in patients with pharyngitis are shown in Table 3.

It is worth noticing that the accuracies of the appropriate diagnosis of the GAS status based upon clinical assessment with the application of CS, amounting to, respectively, $70.3 \%$ $(71 / 101)$ for the sub-group of patients whose score was 4 and $63.4 \%(64 / 101)$ for those whose scores were 3 or 4 , were significantly lower in comparison with the situation in which, after an initial qualification (at least CS2), RADT was performed. Here, the accuracy amounted to $97 \%$ (whereas for both of the comparisons $p$ was $<0.001$ ).

Anti-microbial treatment was prescribed in the case of 59 patients. All RADT-positive individuals received the treatment, including 2 patients that were culture-negative (false positive RADT). Nearly half of 77 RADT-negative cases $(45.5 \%, n=35)$ received an antibiotic, and this group included: 1 patient who was culture-positive for GAS (false-negative RADT result), 10 patients who were culture-positive for non-GAS (with an abundant growth in 8 cases) and 24 patients who were culture-negative (i.e. $40.7 \%$ of individuals who were prescribed an antibiotic).

\begin{tabular}{|c|c|c|c|c|}
\hline \multirow{2}{*}{$\begin{array}{l}\text { Centor } \\
\text { criteria }\end{array}$} & \multicolumn{4}{|c|}{ Result of the culture } \\
\hline & $\begin{array}{l}\text { GAS } \\
(n=23)\end{array}$ & $\begin{array}{l}\text { Non-GAS } \\
(n=13)\end{array}$ & $\begin{array}{l}\beta-H S \\
(n=36)\end{array}$ & $\begin{array}{l}\text { Negative } \\
(n=65)\end{array}$ \\
\hline $\begin{array}{l}\text { Tender an- } \\
\text { terior LA }\end{array}$ & $18(78 \%)$ & $11(85 \%)$ & 29 (81\%) & $42(65 \%)$ \\
\hline Exudate & $21(91 \%)^{a}$ & $12(92 \%)^{b}$ & $33(92 \%)^{c}$ & $39(60 \%)^{a, b, c}$ \\
\hline Fever & $14(61 \%)$ & 10 (77\%) & 24 (67\%) & 38 (58\%) \\
\hline No cough & 22 (96\%) & $10(77 \%)$ & 32 (89\%) & $53(82 \%)$ \\
\hline $\begin{array}{l}2 \text { of the } \\
\text { above- } \\
\text { mentioned }\end{array}$ & $3(7.9 \%)$ & $2(5.3 \%)^{d}$ & $5(13.2 \%)^{d}$ & $33(86.8 \%)$ \\
\hline $\begin{array}{l}3 \text { of the } \\
\text { above- } \\
\text { mentioned }\end{array}$ & $10(27 \%)$ & $5(13.5 \%)^{d}$ & $15(40.5 \%)^{d}$ & 22 (59.5\%) \\
\hline $\begin{array}{l}\text { All of the } \\
\text { above }\end{array}$ & $10(38.4 \%)$ & $6(23.1 \%)^{d}$ & $16(61.5 \%)^{d}$ & $10(38.5 \%)$ \\
\hline
\end{tabular}

${ }^{\mathrm{a}}-p=0.005,{ }^{\mathrm{b}}-p=0.025,{ }^{\mathrm{c}}-p<0.001,{ }^{\mathrm{d}}-$ in each of these groups, a low growth of non-GAS was observed in one patient.

Abbreviations: $\beta$-HS, $\beta$-hemolytic streptococci; GAS, group $A \beta$-hemolytic streptococci (S.pyogenes); LA, lymphadenopathy; non-GAS, other (non-A) groups of $\beta$-hemolytic streptococci.

Penicillin $\vee$ was prescribed to 22 out of 59 patients (37.3\%). In the remaining cases, the following anti-microbial treatment was implemented: cefadroxil -11 patients $(18.6 \%)$, amoxicillin with clavulanic acid -8 patients (13.6\%), amoxicillin -7 patients (11.9\%), macrolides -6 patients (10.2\%), cefuroxime axetil -4 patients $(6.8 \%)$, fluconazole, ciprofloxacin and metronidazole - 1 patient each (1.7\%); 2 individuals received 2 antibiotics (combinations: cefadroxil + clarithromycin and penicillin $\mathrm{V}+$ metronidazole).

The economic analysis of various scenarios for the management of patients with pharyngitis and with at least CS2 (objective: treating cases caused by GAS) is summarized in Table 4 .

The analysis of the structure of the antibiotic therapy used in patients based upon the CS and the adopted criterion of the adequacy of treatment (GAS or abundant growth of any potentially pathogenic $\beta$-HS) is presented in Table 5 .

\begin{tabular}{|c|c|c|c|c|c|}
\hline & $\begin{array}{l}\text { Treatment } \\
\text { recommended/ } \\
\text { prescribed in the } \\
\text { current study }\end{array}$ & $\begin{array}{l}\text { Treat only RADT } \\
\text { positive cases }\end{array}$ & $\begin{array}{l}\text { Treat only GAS(+) } \\
\text { (culture-positive) } \\
\text { cases }\end{array}$ & $\begin{array}{l}\text { Treat patients } \\
\text { with CS3-4 (NICE) }\end{array}$ & $\begin{array}{l}\text { CS2-3: RADT } \\
\text { CS4: atb }\end{array}$ \\
\hline Unnecessary atb prescription & 36 & 2 & 0 & 43 & 17 \\
\hline $\begin{array}{l}\text { No application of atb in cases } \\
\text { of } \mathrm{GAS}(+)=\text { atb underuse }\end{array}$ & 0 & 1 & 0 & 3 & 1 \\
\hline Appropriate treatment* & 62 & 98 & 101 & 55 & 83 \\
\hline Correct atb use & 23 & 22 & 23 & 20 & 22 \\
\hline Total no. of atb prescriptions & 59 & 24 & 23 & 63 & 39 \\
\hline $\begin{array}{l}\text { Cost per patient with ap- } \\
\text { propriate (GAS-oriented) } \\
\text { treatment }\end{array}$ & $\begin{array}{l}\text { 19.93 PLN } \\
\text { (4.62 EUR) }\end{array}$ & $\begin{array}{l}\text { 12.46 PLN } \\
\text { (2.89 EUR) }\end{array}$ & $\begin{array}{l}29.87 \text { PLN } \\
\text { (6.93 EUR) }\end{array}$ & $\begin{array}{l}\text { 29.37 PLN } \\
\text { (6.81 EUR) }\end{array}$ & $\begin{array}{l}\text { 17.46 PLN } \\
\text { (4.05 EUR) }\end{array}$ \\
\hline
\end{tabular}

* atb in the case of GAS(+) patients or symptomatic treatment in the case of GAS(-) patients.

Abbreviations: atb, antibiotic; CS, Centor score; GAS, group A $\beta$-hemolytic streptococci (S. pyogenes); NICE, the National Institute for Health and Care Excellence; RADT, rapid antigen detection test. 


\begin{tabular}{|c|c|c|c|c|c|}
\hline \multirow{2}{*}{$\begin{array}{l}\text { Centor score } \\
\text { (CS) }\end{array}$} & \multirow{2}{*}{$\begin{array}{l}\text { Atb use in this } \\
\text { study }\end{array}$} & \multicolumn{4}{|l|}{ Criterion } \\
\hline & & $\begin{array}{l}\text { Treat only cases with } \\
\text { GAS(+) culture result }\end{array}$ & $\begin{array}{l}\text { Treat only RADT(+) } \\
\text { cases }\end{array}$ & $\begin{array}{l}\text { Unjustified atb use in } \\
\text { this study }\end{array}$ & $\begin{array}{l}\text { Treat only cases with } \\
\text { abundant growth of } \beta \text {-HS }\end{array}$ \\
\hline $\operatorname{CS} 2(n=38)$ & $11(28.9 \%)^{a}$ & 3 (7.9\%) & 2 (5.3\%) & $8(21.0 \%)$ & 4 (10.5\%) \\
\hline $\operatorname{CS} 3(n=37)$ & $23(62.2 \%)$ & $10(27 \%)$ & $11(29.7 \%)$ & $13(35.1 \%)^{b}$ & $14(37.8 \%)$ \\
\hline $\operatorname{CS} 4(n=26)$ & 25 (96.1\%) & $10(38.5 \%)$ & 11 (42.3\%) & $15(57.7 \%)^{b}$ & $15(57.7 \%)$ \\
\hline $\begin{array}{l}\text { Total } \\
(n=101)\end{array}$ & 59 (58.4\%) & $23(22.8 \%)$ & $24(23.8 \%)$ & $36(35.6 \%)$ & $33(32.7 \%)$ \\
\hline
\end{tabular}

a - an antibiotic was also prescribed to one patient with a negative RADT result; S. pyogenes was grown from this patient's throat swab culture.

${ }^{b}$ - unjustified prescription of an antibiotic to one patient might have resulted from a false-positive RADT result.

Abbreviations: atb, antibiotic; $\beta$-HS, beta-hemolytic streptococci GAS; group A $\beta$-hemolytic streptococci (S. pyogenes); RADT, rapid antigen detection test.

\section{Discussion}

This study gives rise to the conclusion that among young adult patients with moderate and severe pharyngitis (characterized by at least 2 Centor criteria), the etiology of the disease was most frequently non-streptococcal. Most likely, the majority of those cases were related to viral infections. This remark has important practical consequences, as those individuals did not require any antibiotic therapy.

Nevertheless, in slightly over one-third of those study participants, $\beta$-HS were found in the throat swab culture; in the majority of them $(91.7 \%, n=33)$, abundant bacterial growth was observed. In accordance with expectations [5-7], the dominant group (69.7\%) was that of GAS, while in the case of the remaining patients - the representatives of other serological groups (non-GAS) were discovered.

GAS constitute the most important cause of pharyngitis justifying antibiotic therapy $[4,8,9]$. Our analysis shows that the basic limitations of the gold standard of the microbiological diagnostics of this clinical syndrome, the objective of which is to identify GAS (time of waiting for result and costs), may be circumvented by the use of RADT. The sensitivity and specificity of this test in the study being discussed here exceeded the values provided by Stewart et al. in the meta-analysis relevant to 1216 adults with pharyngitis [10]. It is worth adding that a Polish study, which provides similar observations on the adequacy of RADT in the case of children, has been published recently [11]. What is significant is that the application of RADT in making therapeutic decisions not only makes it possible to use antibiotics justifiably (epidemiological aspect, limiting side effects), but is also cost-effective. Similar conclusions were formulated by other researchers as well [7]. In connection with the above, we think that there is an urgent need to popularize the application of these tests by general practitioners in Poland.

This requires a comment that, despite the use of RADT in our study, the frequency of prescribing antibiotic treatment to patients with negative RADT results was surprisingly high (45\%). A similar phenomenon was observed in some analyses from different countries (Spain, Sweden and USA), although this frequency was slightly lower (30-40\% of cases) [12-14]. This was probably due to the lack of experience in the application of RADT on the part of physicians, as well as insufficient knowledge of its diagnostic accuracy [14]. Moreover, they might have suspected that other significant bacteria, e.g. the streptococci from groups different than A (non-GAS) or Fusobacterium necrophorum, were the cause of infection, while their presence was impossible to be detected with the use of this test. It is also possible that other factors, like inappropriate habits of physicians and misconceptions about patients' expectations, could play an important role when deciding about antibiotic therapy despite the negative results of RADT.

The growth of non-GAS in the throat swab culture in the case of some patients justified the prescription of antibiotics. The points in favor of finding the less frequent serological groups of $\beta$-HS to be the causal factor of pharyngitis in the case of these persons are: a more frequently ascertained abundant bacterial growth in patients with non-GAS-positive culture (versus the control group), as well as the fact that the CS of the majority of them (9/10) was 3 or 4 .

Although the role of non-GAS as etiological factors of pharyngitis was confirmed in a few earlier reports $[5,6,15,16]$, the procedure in such cases has not been conclusively determined, and numerous recommendations (including the Polish ones as well) put the emphasis on diagnosing and treating cases connected with GAS $[4,8,9]$.

This results from several premises. First, it is not possible to definitely determine the actual connection between the presence of $\beta$-HS (in this age group, non-GAS much more often than GAS are responsible for the carrier state in patients) and its role in causing the symptoms of pharyngitis in the case of a particular patient or viral superinfection as the source of the condition in the case of the carrier of these bacteria [17]. Second, cases of pharyngitis with non-GAS etiology are usually self-limited, and complications - although possible - are infrequent in the descriptions of the disease [8]. Third, an additional difficulty in confirming the participation of these bacteria in causing the symptoms is connected with the necessity of performing a throat swab culture.

Nevertheless, because non-GAS may be the cause of pharyngitis with the same clinical course as those caused by GAS [6, 16], and performing microbiological diagnostics taking under consideration this etiology is not cost-effective, as it is suggested by observations from this study (data not shown), antibiotic therapy will continue to be prescribed in excess by physicians, in particular in more severe cases (Table 5). In this context, it is also worth emphasizing that the presence of one additional Centor criterion increased more than three-fold the likelihood of isolating both GAS (from $7.9 \%$ to $27 \%$ ) and any other potentially significant $\beta$-HS (from $13.2 \%$ to $40.5 \%$ ), and if the patient's CS was 4, this likelihood was over four times higher $(38.5 \%$ and $61.5 \%$, respectively) than for persons with CS2.

The results of our analysis, considered in the light of the available Polish data, indicate that the physicians treating the study participants first and foremost changed the profile of the prescribed antibiotics, most frequently using penicillin V. What is of importance is that the application of amoxicillin, amoxicillin with clavulanate and macrolides together matched the frequency of prescribing a first-choice narrow-spectrum drug. Panasiuk et al. reported that in 424 cases of pharyngitis (Lublin Region, eastern Poland), antibiotics were prescribed in $87.5 \%$ of them, preferring amoxicillin (35.6\%), amoxicillin with clavulanate (13.2\%), as well as macrolides (10.4\%); penicillin $\mathrm{V}$ was prescribed only once $(0.2 \%)$ [2]. According to the Polish results of the international Happy Audit 2 (in which family medicine educational centers from 10 cities, including Poznan, participated), based on the analysis of 5137 visits by patients with respiratory system infections, antibiotics were prescribed in $37 \%$ of the cases, with amoxicillin, amoxicillin with clavulanate and macro- 
lides used in, $28.9 \%, 24.4 \%$ and $22.4 \%$, respectively, of patients undergoing anti-bacterial treatment and penicillin $\mathrm{V}$ in $6.7 \%$ of patients [18].

Summarizing the considerations above, we propose that, in Poland, the prescription of antibiotics in RADT-negative cases of more severe pharyngitis ( 3 or 4 Centor criteria) should be permitted, intensively promoting a delayed prescription of the drug in these cases (e.g. by issuing a prescription that may be filled 24-48 hours after the visit) - this exclusively concerns penicillin V. In our opinion, the application of this strategy may result in a more reasonable prescription of anti-microbial treatment in real-life setting [19] than is the case nowadays. In the case of patients with severe hypersensitivity reactions to penicillin in the past, it would be necessary to conduct microbiological diagnostics.

This study has certain limitations. The most important ones are: a comparatively small number of participants and the lack of the possibility to assess the outcome of patients with pharyngitis. Third, we were unable to conduct diagnostics for infections caused by Fusobacterium necrophorum. This is a microorganism frequently reported as an important cause of pharyngitis in youth and young adults, sometimes complicated by Lemierre's syndrome [20, 21]. Moreover, it needs to be remembered that the diagnostic efficacy of the gold standard in diagnosing the bacterial etiology of pharyngitis, namely, the throat swab culture, is not perfect, and false positive results (e.g. in the case of carriers), as well as false negative ones, are possible [4]. Finally, there was no control group in our study including patients with moderate to severe pharyngitis for whom therapeutic decisions would be made exclusively upon the basis of the clinical history, without access to RADT.

Despite these limitations, facing an acute lack of Polish studies in this field and, at the same time, given the fact that the results obtained by us and the conclusions from larger analyses conducted by other researchers working on the problem being discussed here coincide, we believe that this report will prove to be useful in the daily practice of physicians in Poland.

\section{Conclusions}

In young adult pharyngitis patients with CS2-4, $\beta$-HS are responsible for a minority of cases.

Among these bacteria, one third are non-GAS. Centor criteria, as the only diagnostic tool in predicting the streptococcal etiology of the disease, are of moderate usefulness. The use of RADT significantly increases the diagnostic accuracy of GAS-related pharyngitis.

Source of funding: This work was funded by Poznan University of Medical Sciences: the first edition (2013) of the 'Give a Hand' ("Podaj rękę") program - the initiative of the Dean of the Second Faculty of Medicine.

Conflict of interest: The authors declare no conflict of interests.

\section{References}

1. Hryniewicz W, Ozorowski T, Radzikowski A, et al. Rekomendacje postępowania w pozaszpitalnych zakażeniach układu oddechowego 2010 [cited: 25.06.2015]. Available from URL: http://www.antybiotyki.edu.pl/pdf/RekomendacjeA42009.pdf.

2. Panasiuk L, Lukas W, Paprzycki P, et al. Antibiotics in the treatment of upper respiratory tract infections in Poland. Is there any improvement? J Clin Pharm Ther 2010; 35(6): 665-669.

3. Gulliford MC, Dregan A, Moore MV, et al. Continued high rates of antibiotic prescribing to adults with respiratory tract infection: survey of 568 UK general practices. BMJ Open 2014; 4(10): e006245.

4. Hryniewicz W, Albrecht P, Radzikowski A, et al. Rekomendacje postępowania w pozaszpitalnych zakażeniach układu oddechowego 2016 [cited: 10.06.2015]. Available from URL: http://antybiotyki.edu.pl/pdf/Rekomendacje2016.pdf.

5. Lindbaek M, Høiby EA, Lermark $G$, et al. Clinical symptoms and signs in sore throat patients with large colony variant $\beta$-haemolytic streptococci groups C or G versus group A. Br J Gen Pract 2005; 55(517): 615-619.

6. Little P, Hobbs FD, Mant D, et al. PRISM investigators. Incidence and clinical variables associated with streptococcal throat infections: a prospective diagnostic cohort study. Br J Gen Pract 2012; 62(604): e787-e794.

7. Humair JP, Revaz SA, Bovier P, et al. Management of acute pharyngitis in adults: reliability of rapid streptococcal tests and clinical findings. Arch Intern Med 2006; 166(6): 640-644.

8. Pelucchi C, Grigoryan L, Galeone C, et al. ESCMID Sore Throat Guideline Group. Guideline for the management of acute sore throat. Clin Microbiol Infect 2012; 18(Suppl. 1): 1-28.

9. Shulman ST, Bisno AL, Clegg HW, et al. Clinical practice guideline for the diagnosis and management of group A streptococcal pharyngitis: 2012 update by the Infectious Diseases Society of America. Clin Infect Dis 2012; 55(10): e86-e102.

10. Stewart EH, Davis B, Clemans-Taylor BL, et al. Rapid antygen group A streptococcus test to diagnose pharyngitis: a systematic review and meta-analysis. PLoS ONE 2014; 9(11): e111727.

11. Mazur E, Bochyńska E, Juda M, et al. Empirical validation of Polish guidelines for the management of acute streptococcal pharyngitis in children. Int J Pediatr Otorhinolaryngol 2014; 78(1): 102-106.

12. Linder JA, Chan JC, Bates DW. Evaluation and treatment of pharyngitis in primary care practice: the difference between guidelines is largely academic. Arch Intern Med 2006; 166(13): 1374-1379.

13. Neumark T, Brudin L, Mölstad S. Use of rapid diagnostic tests and choice of antibiotics in respiratory tract infections in primary healthcare - a 6-y follow-up study. Scand J Infect Dis 2010; 42(2): 90-96.

14. Llor $\mathrm{C}$, Madurell J, Balagué-Corbella M, et al. Impact on antibiotic prescription of rapid antigen detection testing in acute pharyngitis in adults: a randomised clinical trial. Br J Gen Pract 2011; 61(586): e244-e251.

15. Zwart S, Ruijs GJ, Sachs AP, et al. Beta-haemolytic streptococci isolated from acute sore-throat patients: cause or coincidence? A casecontrol study in general practice. Scand J Infect Dis 2000; 32(4): 377-384.

16. Tiemstra J, Miranda RL. Role of non-group a streptococci in acute pharyngitis. J Am Board Fam Med 2009; 22(6): 663-669.

17. Bura $M$, Michalak M, Padzik M, et al. The carriage of potentially pathogenic $\beta$-haemolytic streptococci ( $\beta$-HS) in healthy adult inhabitants of Wielkopolska, Poland. Fam Med Prim Care Rev 2016; 18(3): 221-224.

18. Strumiło J, Chlabicz S, Ovhed I, et al. Management of respiratory tract infections in primary care in Poland - results of the Happy Audit 2 project. Prz Epidemiol 2014; 68(1): 33-38.

19. Little P, Stuart B, Hobbs FD, et al. DESCARTE investigators. Antibiotic prescription strategies for acute sore throat: a prospective observational cohort study. Lancet Infect Dis 2014; 14(3): 213-219.

20. Centor RM. Expand the pharyngitis paradigm for adolescents and young adults. Ann Intern Med 2009; 151(11): 812-815.

21. Kuppalli K, Livorsi D, Talati NJ, et al. Lemierre's syndrome due to Fusobacterium necrophorum. Lancet Infect Dis 2012; 12(10): 808-815. 
Tables: 5

Figures: 0

References: 21

Received: 11.08.2016

Revised: 22.09.2016

Accepted: 12.10.2016

Address for correspondence:

Maciej Bura, MD, PhD

Klinika Chorób Zakaźnych, Hepatologii

i Nabytych Niedoborów Odporności UM

ul. Szwajcarska 3

61-285 Poznań

Polska

Tel.: +48 618 739-376

E-mail:mbura@umed.poznan.pl 